\title{
Fertility Capability Classification of Soils in Two Agro Ecological Zones in the Basement Complex Zone of Nigeria
}

\author{
Babalola, T.S. ${ }^{1}{ }^{*}$, Fasina, A.S. ${ }^{2}$, Kadiri, W.O.J. ${ }^{1}$, Omonile, T. ${ }^{1}$, Ibitoye-Ayeni, N.K. ${ }^{1}$, Mohammed, \\ S.A. ${ }^{1}$ \\ ${ }^{l}$ Kabba College of Agriculture, Division of Agricultural Colleges, Ahmadu Bello University, Nigeria. \\ ${ }^{2}$ Department of Soil Science, Federal University, Oye, Nigeria.
}

*Corresponding Author: Babalola, T.S., Kabba College of Agriculture, Division of Agricultural Colleges, Ahmadu Bello University, Nigeria.

\begin{abstract}
There is need to evaluate the fertility status of soils for sustainable soil management and productivity. The fertility capability of soils in two agro-ecological zones of Nigeria was evaluated. This is with the view of identifying limitations and management problems in terms of the nutrient supplying capacity of the soils. Seven soil pedons were identified in Ado-Ekiti (dry upland rainforest) and nine in Kabba (southern guinea savannah) in a 12 hectares land each. Soils samples were collected at the top and subsoil and analyzed for physical and chemical properties. The soils were predominantly loamy textured at the surface and loam to sand and clay textured at the subsurface. Major limitations observed at Kabba are high gravel percentage, $\left(r^{+}\right)$and anaerobic condition $\left(g^{+}\right)$while low nutrient capital $K$ was observed at Ado-Ekiti. Low buffering capacity (e) and ustic moisture regime are limitations common to both locations. Management practices suggested include the utilization of wetland areas for rice production, application of fertilizer in split doses and adoption of legumes into crop production.
\end{abstract}

Keywords: fertility, evaluation, limitations, use, management

\section{INTRODUCTION}

The development and survival of human of the human race is based on the performance of soils and its ability to productive in other to meet human food demand (Hillel, 2009) and the sustainable use of the soil in other to ensure food supply to the geometrically increasing world population have become one of the global issues of the $21^{\text {st }}$ century (Lal, 2008, 2009; Jones et al., 2009; Lichtfouse et al., 2009).

There has been decline in soil fertility in sub-Saharan zone of the world (Sanchez, 2002) which constitute serious threat to agricultural production and the performance of soils. The decline in soil fertility had been attributed to inadequate use of fertility inputs, on-going soil degradation, and increasingly intense land use without organic and mineral inputs to improve on soil fertility by burgeoning populations (St. Clair and Lynch, 2011). The rising temperature, drought, intense precipitation and other adverse weather conditions occasioned by the prevailing climate change could worsening the decline of soil fertility in the tropics (St. Clair and Lynch, 2011; Tabi et al. 2013).

Handling of soils by societies must be in a sustainable way in order to maintain its fertility and ensure that it is productive (Rao and Rogers, 2006; Hillel, 2009). It is also important to have information on the fertility status of the soil; this will go a long way as a guide for land users in other to develop proper management practices that will guarantee sustainable productivity. This can be achieved through Fertility Capability Classification (FCC).

The fertility capability classification (FCC) system was developed as an attempt to bridge the gap between sub-disciplines of soil classification and soil fertility, especially to interpret soil taxonomy and additional soil attributes in a way that is directly relevant to the plant growth (Zehetner and Miller, 2006; Geissen et al. 2009; Das, 2015). It accesses the soil function in relation to its capacity to supply nutrients to growing crops (Sanchez et al., 2003), in that it considers the top soil believed to be the root zone of growing crops. 
There is no report on fertility assessment data for the study areas. Soil management practices in are based on indigenous understanding and blanket recommendations, this will not guarantee sustainability and proper adoption/implementation of improved soil and crop management practices. Therefore, there is need for scientific understanding of the fertility of the soil around areas in other to guide in the management of the soils for optimum crop production.

The objective of this study is to evaluate the capability of the soils in the study area to sustain crop production using fertility capability classification.

\section{Materials AND Methods}

Ado-Ekiti is situated in Ekiti State of South Western Nigeria. The research site lies between latitude $7.710802 \mathrm{~N}$ and $7.713800 \mathrm{~N}$ and longitude $5.243230 \mathrm{E}$ and $5.246470 \mathrm{E}$. The climate is of the upland Tropical Rain Forest type with distinct wet and dry seasons.

Kabba this is located in the western part of Kogi State of the North Central Nigeria and The research site lies between latitude $7.860376 \mathrm{~N}$ and $7.862225 \mathrm{~N}$ and longitude $6.069576 \mathrm{E}$ and $6.074468 \mathrm{E}$. The area lies within the southern guinea savanna zone of Nigeria.

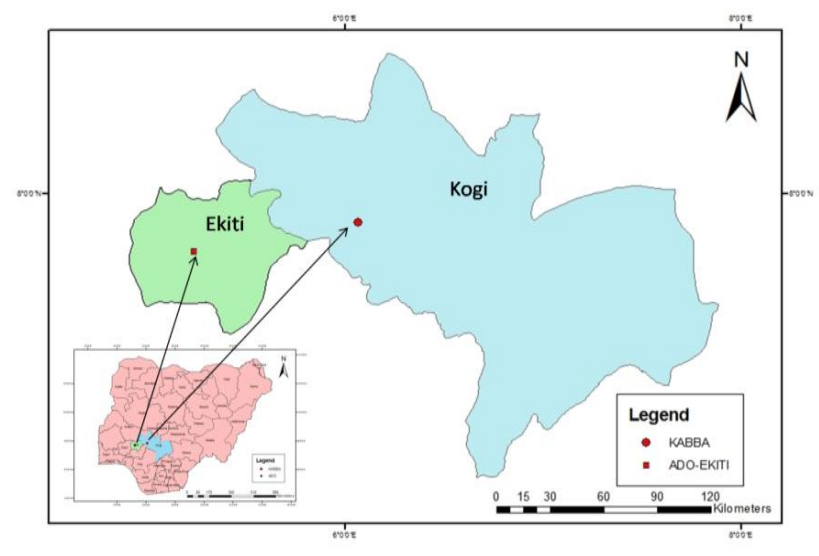

Figure1. Map of Nigeria Showing the Location of the Two Sites

Soil Survey and Sampling: Each of the location (Ado-Ekiti and Kabba) was mapped. The conventional method of soil survey involving rigid grid procedure was adopted. For both sites, observations were made along traverses of $50 \mathrm{~m}$ apart with soil auger. Soil morphological properties were described in the field following the procedure described in the USDA Soil Survey manual (Soil Survey Staff, 2014). Areas with same soil type were mapped together and plotted on a base map. An area of 12.4395 and 12.1841 hectares of land were mapped in Ado Ekiti and Kabba respectively. Soil map of the two locations are presented in figure 1 and 2. Soil profiles within each soil boundaries were dug, described and sampled. Soil samples collected were taken to the laboratory for analysis.

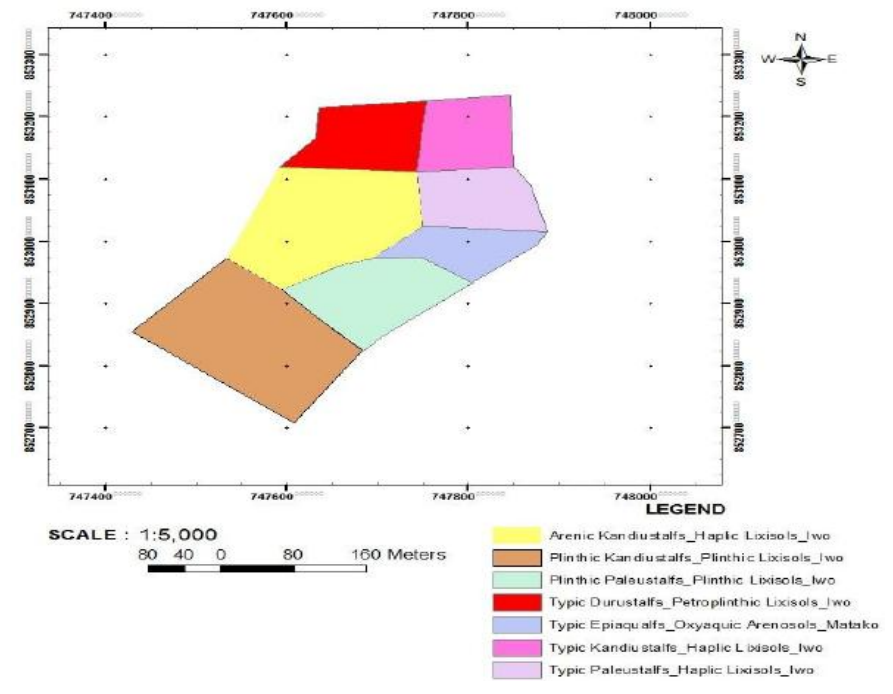

Figure2. Soil map of Ado-Ekiti study site 


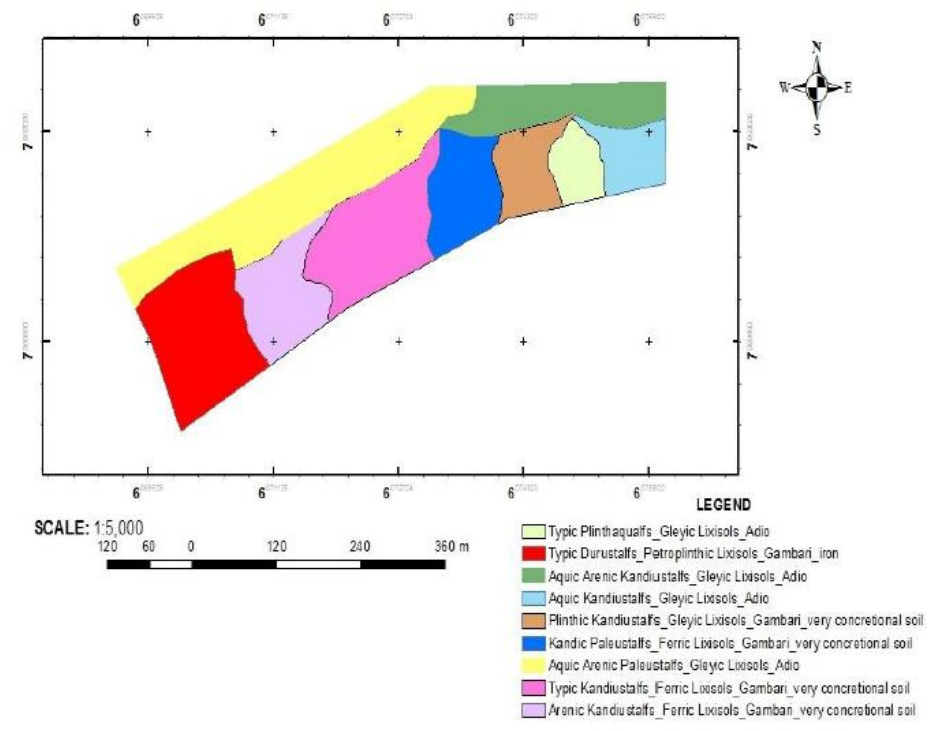

Figure3. Soil map of Kabba study site

Laboratory analyses: Soil samples collected from the various pedogenic horizons were air-dried in the laboratory, crushed with porcelain pestle and mortar and sieved to remove, material greater than $2 \mathrm{~mm}$ (gravel). Percent gravel to total soil was calculated. The less than $2 \mathrm{~mm}$ materials were used to carry out Laboratory analysis for physico-chemical properties. Particle size distribution was determined using the modified hydrometer method (Bouyoucos, 1951). Soil pH was measured electrometrically in water at 1: 1 soil to liquid (weight/volume) ratio. Organic carbon was determined by the Walkley-Black wet oxidation method (Walkey and Black, 1965) and total nitrogen was obtained by the micro-Kjeldahl method (Bremner, 1996). Available phosphorus was extracted with Bray-1solution and the $\mathrm{P}$ was determined using the ammonium molybdate-blue method (Bray and Kurtz, 1945). Exchangeable cations ( $\mathrm{Ca}, \mathrm{Mg}, \mathrm{K}$ and $\mathrm{Na}$ ) were extracted with neutral, normal ammonium acetate solution. Calcium $(\mathrm{Ca})$ and $\mathrm{Mg}$ were determined by atomic absorption spectrophotometry while $\mathrm{K}$ and $\mathrm{Na}$ were determined by flame emission photometry. Exchangeable acidity was extracted with a molar solution of $\mathrm{KCl}$ and determined titrometrically. Effective cation exchange capacity, exchangeable sodium saturation and based saturation were calculated. The results of the analysis are presented in table 1 and 2.

Fertility Capability Classification: This was carried out using the FCC Version 4 by Sanchez et al., (2003).

\section{RESULTS AND DISCUSSION}

Fertility capability classification (FCC) evaluation was carried out for the soils studied at the two locations. Physico-chemical properties in Table 1 and 2 were used for the classification by comparing them with FCC version 4 framework. The framework consists of two categorical levels. The first category- type/substrata type- describes topsoil (0-20 cm depth) and subsoil (0-50cm depth) texture and is expressed in capital letter. The second category- condition modifiers consist of modifiers defined to delimit specific soils conditions affecting plant growth with quantitative limits. Each condition is expressed as a lower case letter. Superscript + or - indicate a greater or lesser expression of the modifier. The summary of FCC is presented in table 3 and FCC maps in figures 3 and 4.

In the first category- type all the profiles were classified as L. This indicates that the soils have loamy topsoil with moderate to well-drained soil and good water holding capacity. At the substrata type level Profiles AA, AE and AF are classified as $\mathrm{C}$ this indicates that the sub soils underlying the top soil is clayey and will have low infiltration and high water holding capacity. AG was classified as $\mathrm{S}$ this indicates that the subsoil is sandy and will be porous. All other soils considered were classified as L this indicates that they have a loamy subsoil underlying the top soil. This is a pointer that the soils will have good infiltration and water holding capacity.

At the second category profiles $\mathrm{KC}, \mathrm{KF}$ and $\mathrm{KG}$ were classified as $\mathrm{g}^{+}$and it indicates the soils have gleyic properties within $50 \mathrm{~cm}$ of the soils depth. This is an evidence that these soils are being flooded 
Fertility Capability Classification of Soils in Two Agro Ecological Zones in the Basement Complex Zone of Nigeria

or water logged at a period of the year. These soils can support intensive agriculture in the production of rice during the wet period (Sanchez and Buol, 1985) and dry season farming as widely practiced all over Africa (Sanchez et al., 2003). All the profiles with the exception of Profile AG were rated with d modifier; this implies that the soils have an ustic moisture regime. This favours soil dynamics such as slowing down of nitrogen mineralization and leaching as well as the death of many soil microorganisms (Sanchez et al., 2003). However it may limit round the year production of crops except supplementary is supplied through irrigation. AG was rated $g$ it implies that the soils has an aquic condition, this could be as a result of its lowland position in the landscape. The high water table will make crop cultivation to be greatly limited to crops adapted to high water table during the wet season. All the profiles on the schist parent materials were rated $\mathrm{r}^{+}$. This implies that the soils contain gravel percentage that falls within the range of $10-35 \%$. This may constitute impediment to tillage, most especially in mechanized tillage. All the soils are rated with modifier e. This indicates that the soils have low nutrient retaining ability hence high leaching potential. This could be as a result of prevalent granulated clayey soils with low activity clay minerals.

The aggregate fertility capabilities of the soils are as follows: KA, KB, KD, KE and KI were classified as $\mathrm{LLdr}^{+} \mathrm{e}, \mathrm{KC}, \mathrm{KF}$ and $\mathrm{KG}$ is $\mathrm{LLg}^{+} \mathrm{dr}^{+} \mathrm{e}, \mathrm{AA}$ and $\mathrm{AF}$ as LCde, $\mathrm{AB}$ and $\mathrm{AD}$ as LLde, $\mathrm{AC}$ as LLdke, $\mathrm{AE}$ as LCdke and $A G$ as LSge.

\section{CONCLUSION AND RECOMMENDATION}

The soils of the study areas were observed to be limited by high gravel percentage, $\left(\mathrm{r}^{+}\right)$, anaerobic condition $\left(\mathrm{g}^{+}\right)$, low nutrient capital $\mathrm{K}$, low buffering capacity (e) and ustic moisture regime.

The following management practices were suggested the utilization of wetland areas for dry season vegetable, rice and sugar cane production or other crops that can support anaerobic condition, application of potassium $(\mathrm{K})$ rich fertilizer, application of fertilizer in split doses with integration of organic manure, adoption of legumes into crop rotation and agroforestry involving leguminous shrubs.

Table1. Physico-Chemical characteristics of Kabba study area (Schists Belt)

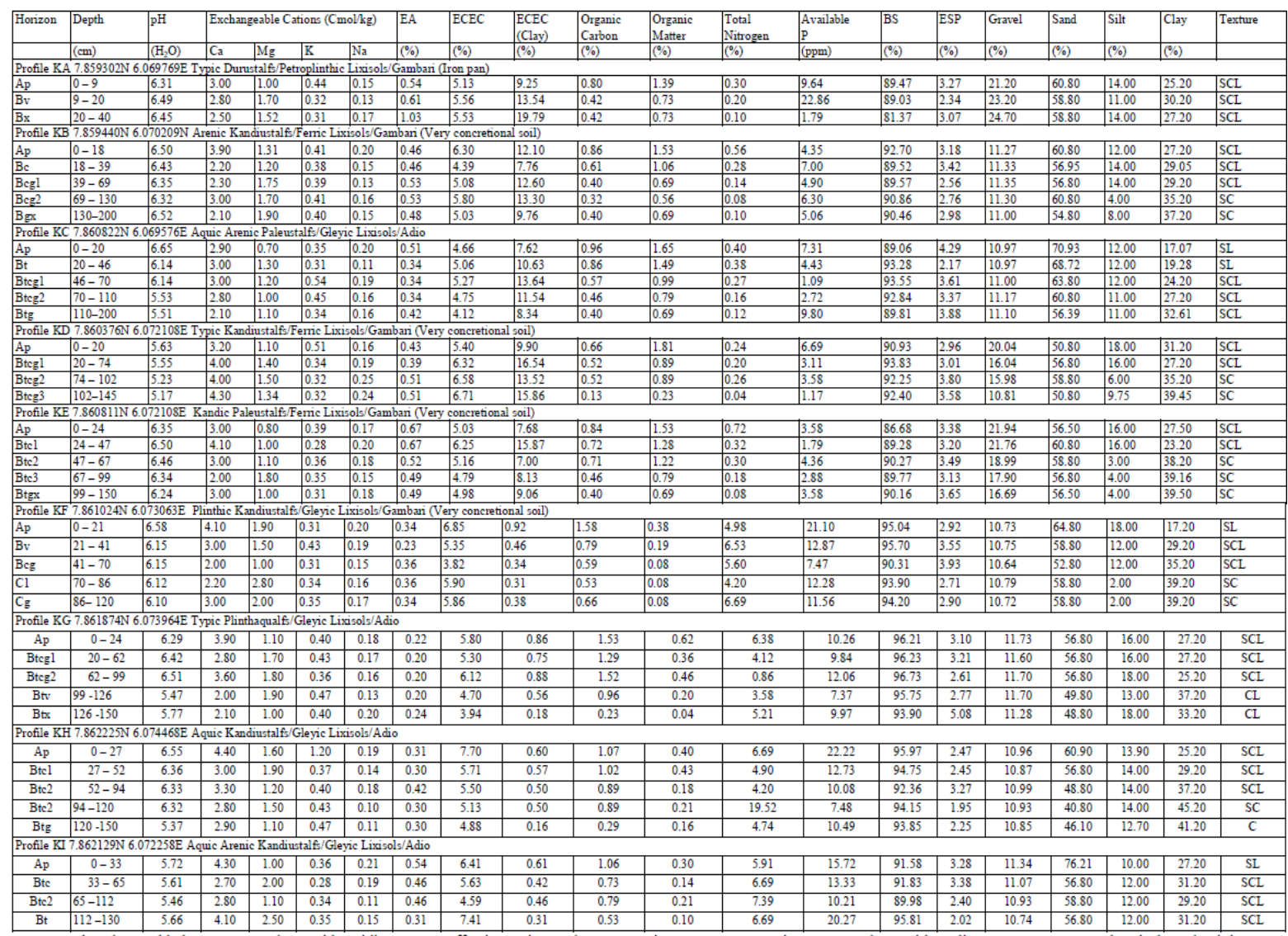

TEB-Total exchangeable bases EA-Exchangeable acidity ECEC-Effective cation exchange capacity BS-Base saturation ESP-Exchangeable sodium percentage, EC-Electrical conductivity

International Journal of Research Studies in Agricultural Sciences (IJRSAS) 
Fertility Capability Classification of Soils in Two Agro Ecological Zones in the Basement Complex Zone of Nigeria

Table2. Physico-Chemical characteristics of Ado Ekiti study area (Older Granite)

\begin{tabular}{|c|c|c|c|c|c|c|c|c|c|c|c|c|c|c|c|c|c|c|c|c|}
\hline \multirow{2}{*}{ Hoizon } & \multirow{2}{*}{$\begin{array}{l}\text { Depth } \\
\text { (mi) }\end{array}$} & \multirow{2}{*}{$\begin{array}{l}\mathrm{pH}^{\mathrm{pH}} \\
(\mathrm{H}, \mathrm{O})\end{array}$} & \multicolumn{4}{|c|}{ Exchangeable Catons (Cmolkg) } & $\mathrm{EA}$ & ECEC & \multirow{2}{*}{$\begin{array}{l}\begin{array}{l}\text { Organic } \\
\text { Carbon }\end{array} \\
\text { C. }\end{array}$} & \multirow{2}{*}{\begin{tabular}{|c|}
$\begin{array}{l}\text { Organic } \\
\text { Matter }\end{array}$ \\
$(\%)$ \\
\end{tabular}} & $\begin{array}{c}\text { Total } \\
\text { Nitrogen }\end{array}$ & $\begin{array}{c}\text { Avalable } \\
\text { P }\end{array}$ & ECEC (Clay) & BS & ESP & \multirow[t]{2}{*}{ Gravel } & \multirow[t]{2}{*}{ Sand } & \multirow[t]{2}{*}{ Silt } & \multirow[t]{2}{*}{\begin{tabular}{|l|} 
Clay \\
\end{tabular}} & \multirow[t]{2}{*}{ Textue } \\
\hline & & & $\mathrm{Ca}$ & $\mathrm{Mg}$ & K & $\mathrm{Na}$ & (Cmolkg) & $(\mathrm{Cmolk} / \mathrm{kg})$ & & & (\%) & (gpm) & (Cmolkg) & $(\%)$ & $\%$ & & & & & \\
\hline$A_{p}$ & $0-13$ & 6.2 & 270 & 0.41 & \begin{tabular}{|l|}
0.29 \\
\end{tabular} & 018 & 144 & & & & & 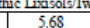 & 1075 & 7131 & 358 & 0.70 & 770 & 800 & & \\
\hline Bt & $\frac{13-}{13-}$ & 6.4 & 1.70 & 0.22 & \begin{tabular}{|l|}
0.17 \\
\end{tabular} & 0.12 & 1.68 & 3.89 & 0.23 & 0.40 & 0.02 & 5.06 & 9.95 & 56.81 & 3.08 & 1.36 & 65.00 & 4.00 & 31.00 & SCI \\
\hline Brvl & $\begin{array}{l}36- \\
36-\end{array}$ & 6.9 & 275 & 0.32 & \begin{tabular}{|l|}
0.19 \\
\end{tabular} & 0.14 & 1.50 & 4.82 & 0.19 & 0.33 & 0.02 & 6.13 & 10.65 & \begin{tabular}{|l|l|}
68.87 \\
\end{tabular} & 290 & 1.45 & 57.00 & 5.00 & 39.00 & SCI \\
\hline Btv2 & $\begin{array}{l}84- \\
118\end{array}$ & 6.5 & 280 & 0.31 & 0.22 & 0.13 & 1.28 & 4.74 & 0.11 & 0.18 & 0.01 & 5.91 & 8.89 & 72.00 & 274 & 2.11 & 47.00 & 4.00 & 49.00 & SC \\
\hline Btex & $\begin{array}{l}118 \\
118- \\
130\end{array}$ & 5.7 & 285 & 0.33 & \begin{tabular}{|l|}
0.21 \\
\end{tabular} & 0.11 & 1.12 & 4.63 & 0.11 & 0.18 & 0.01 & 5.83 & 8.84 & 75.91 & 237 & 4.05 & 46.00 & 6.00 & 48.00 & SC \\
\hline$\frac{A p}{\partial p}$ & $\frac{0-15}{15}$ & 6 & & & & & 0.04 & 77 & . 0.40 & 0.00 & $0.0+$ & 8.94 & 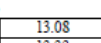 & & & & & 8.000 & & SL \\
\hline & $\begin{array}{l}15- \\
38\end{array}$ & 6.3 & 2.13 & 0.25 & \begin{tabular}{|l|}
0.19 \\
\end{tabular} & 0.14 & 1.04 & 3.75 & 0.50 & 0.88 & 0.04 & 7.00 & 13.33 & 72.26 & 3.73 & 1.20 & 77.00 & 8.00 & 15.00 & SL \\
\hline $\mathrm{Bt} 2$ & $\begin{array}{l}38- \\
68-\end{array}$ & 6.4 & 1.23 & 0.32 & \begin{tabular}{|l|}
0.17 \\
\end{tabular} & 0.14 & 1.12 & 4.03 & 0.44 & 0.76 & 0.03 & 7.39 & 4.94 & 72.20 & 3.47 & 1.27 & 61.00 & 8.00 & 31.00 & SCI \\
\hline Btc & $69-$ & 5.8 & 218 & 0.42 & 0.17 & 0.14 & 1.12 & 4.03 & 0.27 & 0.47 & 0.02 & 5.68 & 7.17 & 7220 & 3.47 & 1.43 & 53.00 & 4.00 & 43.00 & SC \\
\hline Btx & $100-$ & 5.7 & 2000 & 0.42 & \begin{tabular}{|l|}
0.17 \\
\end{tabular} & 0.15 & 1.20 & 3.94 & 0.15 & 0.25 & 0.01 & 14.98 & 7.59 & \begin{tabular}{|l|l|l|}
69.54 \\
\end{tabular} & 3.80 & 1.91 & 49.00 & 6.00 & 45.00 & SC \\
\hline & $0-19$ & 6.7 & 250 & $\overline{02}$ & & & & $\frac{0 \text { ofle } A C}{406}$ & $\frac{56 \mathrm{~N} 5.24}{105}$ & $\begin{array}{l}\text { EAvenin } \\
181\end{array}$ & 09 & tixisols/mu & & & & & & & & \\
\hline 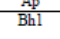 & $19-$ & $\frac{6.1}{6.2}$ & 1.60 & 0.22 & \begin{tabular}{|l|}
0.13 \\
\end{tabular} & $\begin{array}{l}0.07 \\
0.10\end{array}$ & $\frac{1.12}{1.12}$ & $\begin{array}{l}4.06 \\
3.17\end{array}$ & 0.57 & $\frac{1.81}{0.98}$ & $\frac{0.09}{0.05}$ & $\frac{1.493}{10.42}$ & $\begin{array}{ll}2.88 \\
5.88\end{array}$ & \begin{tabular}{|l|l|l|l|}
64.67 \\
6.96
\end{tabular} & $\frac{1.12}{3.16}$ & $\begin{array}{l}0.20 \\
0.80\end{array}$ & 70.00 & 10.00 & 20.00 & SL \\
\hline $\mathrm{Bh} 2$ & $35-$ & 6.1 & 1.18 & 0.28 & \begin{tabular}{|l|}
0.22 \\
\end{tabular} & 0.09 & 1.04 & 2.81 & 0.45 & 0.83 & 0.04 & 8.01 & 4.26 & \begin{tabular}{|l|l|}
63.00 \\
\end{tabular} & 3.20 & 1.65 & 67.00 & 4.00 & 29.00 & SC \\
\hline $\mathrm{Bh} 3$ & $60-94$ & 5.8 & 2.13 & 0.25 & \begin{tabular}{|l|}
0.21 \\
\end{tabular} & 0.10 & 1.08 & 3.77 & 0.82 & 1.41 & 0.07 & 34.61 & 290 & 71.35 & 265 & 2.17 & 63.00 & 6.00 & 31.00 & SC \\
\hline$A_{p}$ & $0-18$ & 6.8 & 2.68 & & & & & $\frac{e A D}{4.47}$ & 0.92 & 1.59 & 0.08 & $\frac{1.450055}{10.58}$ & & & & & & & & \\
\hline $\bar{B}$ & $\begin{array}{l}18- \\
34\end{array}$ & 6.2 & 1.45 & 0.25 & 0.21 & 0.09 & 0.96 & 2.96 & 0.71 & 1.23 & 0.06 & 8.01 & $\frac{0.76}{1.76}$ & 67.57 & 3.04 & 0.80 & 62.00 & 11.00 & 7.00 & $\mathrm{CI}$ \\
\hline Btx & $\begin{array}{l}34- \\
64-\end{array}$ & 6.2 & 1.48 & 0.21 & \begin{tabular}{|l|}
0.19 \\
\end{tabular} & 0.14 & 0.96 & 2.98 & 0.38 & 0.66 & 0.04 & 4.74 & 5.00 & 67.79 & 4.70 & 0.51 & 56.00 & 11.00 & 33.00 & SCI \\
\hline App & & 6.1 & 253 & 0.34 & & & & $\begin{array}{l}\text { Profile AE } 7 . \\
4.17\end{array}$ & $\frac{644 \mathrm{~N} 5.22}{0.77}$ & E Typic & ustallat/Hag & disols/wiwo & & & & & & & & SCI \\
\hline $\mathrm{Bh}$ & $\begin{array}{l}35- \\
79-\end{array}$ & 6.4 & 1.73 & 0.26 & \begin{tabular}{|l|l|l|l} 
& \\
\end{tabular} & 0.11 & 1.12 & 3.43 & 0.76 & 1.30 & 0.06 & 10.11 & 2.20 & 67.35 & 3.21 & 2.61 & 58.00 & 7.00 & .00 & $\overline{S C L}$ \\
\hline Bhx & $79-$ & 6.0 & 1.58 & 0.23 & \begin{tabular}{|l|}
0.19 \\
\end{tabular} & 0.10 & 1.20 & 3.30 & 0.65 & 1.12 & 0.06 & 3.89 & 238 & $\begin{array}{ll}63.64 \\
\end{array}$ & 3.03 & 3.01 & 52.00 & 5.00 & 43.00 & SC \\
\hline & $0-20$ & & & 031 & 0.23 & 012 & & $\frac{7 \text { tofle }}{522}$ & $\frac{2131 \mathrm{~N} 5}{0.07}$ & EAs & 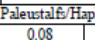 & $\frac{c L i x i s o l s}{224}$ & & & & & & & & \\
\hline$B$ & $\begin{array}{l}20- \\
20-\end{array}$ & $\frac{0.6}{6.5}$ & $\frac{2.68}{1.33}$ & 0.31 & \begin{tabular}{l|l}
0.17 \\
\end{tabular} & $\begin{array}{l}.12 \\
0.07\end{array}$ & $\frac{1.88}{1.44}$ & $\frac{3.22}{3.98}$ & 0.38 & $\frac{153}{0.65}$ & 0.0 .03 & $\frac{22.24}{10.58}$ & 10.80 & $\begin{array}{l}62.00 \\
62.56\end{array}$ & $\frac{230}{1.76}$ & 0.20 & $\frac{74.00}{64.00}$ & $\frac{11.00}{11.00}$ & 5.00 & 2 \\
\hline Bt & $\frac{49-}{49-5}$ & 6.3 & 1.50 & 0.21 & 0.18 & 0.08 & 0.88 & 2.85 & 0.32 & 0.54 & 0.03 & 5.76 & 4.44 & \begin{tabular}{|l|l|l}
69.12 \\
\end{tabular} & 281 & 3.11 & 54.00 & 7.00 & 39.00 & SCI \\
\hline $\mathrm{Btx}$ & $85-$ & 6.0 & 1.53 & 0.20 & 0.16 & 0.15 & 1.12 & 3.16 & 0.23 & 0.40 & 0.02 & 13.77 & 5.48 & 64.56 & 4.75 & 4.60 & 48.00 & 9.00 & 43.00 & c \\
\hline & & & & & & & & & & & & nosole & & & & & & & & \\
\hline$\frac{A \mathrm{p}}{\mathrm{Aw}}$ & $\frac{0-9}{9-20}$ & $\frac{6.5}{5.2}$ & $\begin{array}{l}2.98 \\
1778\end{array}$ & \begin{tabular}{l|l}
0.40 \\
0.18
\end{tabular} & $\begin{array}{l}0.26 \\
0.09\end{array}$ & $\frac{0.18}{0.11}$ & $\frac{1.60}{1.75}$ & $\frac{5.42}{3.91}$ & $\begin{array}{r}1.39 \\
0.04\end{array}$ & $\frac{2.48}{0.76}$ & $\frac{0.21}{0.04}$ & $\frac{13.53}{5.44}$ & $\begin{array}{l}3.96 \\
1.963\end{array}$ & $\begin{array}{l}57.33 \\
39883\end{array}$ & 378 & $\begin{array}{l}1.41 \\
0.68\end{array}$ & $\begin{array}{l}76.00 \\
88000\end{array}$ & 10.00 & & $\frac{1}{5}$ \\
\hline$\frac{\mathrm{Bw} 2}{\mathrm{Bw}}$ & $20-$ & 5.6 & 0.88 & 0.17 & 0.08 & \begin{tabular}{|c|}
0.10 \\
\end{tabular} & 0.72 & 1.95 & 0.08 & 0.15 & 0.01 & 490 & $\frac{2.85}{12.85}$ & 63.08 & 5.13 & 0.20 & 80.00 & 7.00 & 13.00 & IS \\
\hline
\end{tabular}

TEB-Total exchangeable bases EA-Exchangeable acidity ECEC-Effective cation exchange capacity BS-Base saturation ESP-Exchangeable sodium percentage, EC-Electrical conductivity

Table3. Fertility capability classification of soils studied

\begin{tabular}{|c|c|c|c|c|c|c|c|c|c|}
\hline \multirow[t]{2}{*}{ Profile } & \multirow[t]{2}{*}{ Type } & \multirow[t]{2}{*}{ Substrata types } & \multicolumn{6}{|c|}{ Modifiers } & \multirow[t]{2}{*}{ Aggregate } \\
\hline & & & $\mathrm{g}$ & $\mathrm{g}^{+}$ & $\mathrm{D}$ & $r^{+}$ & $\mathrm{K}$ & $E$ & \\
\hline $\mathrm{KA}, \mathrm{KB}, \mathrm{KD}, \mathrm{KE}, \mathrm{KH}, \mathrm{KI}$ & $\mathrm{L}$ & $\mathrm{L}$ & & & + & + & & + & $\mathrm{LLd} \mathrm{r}^{+} \mathrm{e}$ \\
\hline $\mathrm{KC}, \mathrm{KF}, \mathrm{KG}$ & $\mathrm{L}$ & $\mathrm{L}$ & & + & + & + & & + & $\operatorname{LLg}^{+} \mathrm{dr}^{+} \mathrm{e}$ \\
\hline $\mathrm{AA}, \mathrm{AF}$ & $\mathrm{L}$ & C & & & + & & & + & LCde \\
\hline$A B, A D$ & $\mathrm{~L}$ & $\mathrm{~L}$ & & & + & & & + & LLde \\
\hline$A C$ & $\mathrm{~L}$ & $\mathrm{~L}$ & & & + & & + & + & LLdke \\
\hline $\mathrm{AE}$ & $\mathrm{L}$ & C & & & + & & + & + & LCdke \\
\hline AG & $\mathrm{L}$ & $S$ & + & & & & & + & LSge \\
\hline
\end{tabular}

L-Loamy textured, C- Clayey textured, S- Sandy textured $\mathrm{g}^{+}$- anaerobic condition (gley), g- aquatic moisture regime, $\mathrm{d}$ - ustic moisture regime, $\mathrm{r}^{+}$- gravel percentage between 10-35\%, K- low nutrient capital reserves (K deficiencies) e- low buffering capacity ECEC $<10 \mathrm{cmol} / \mathrm{kg}$ soil by sum of EB+EA

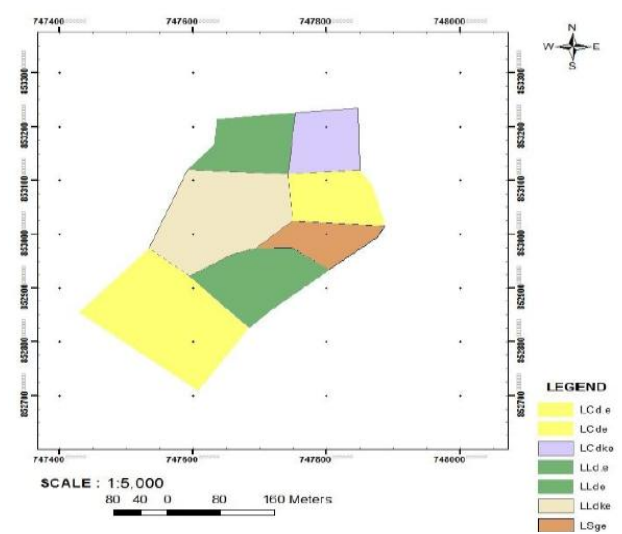

Figure4. Fertility capability classification of Ado Ekiti site (Older granite soils)

International Journal of Research Studies in Agricultural Sciences (IJRSAS) 


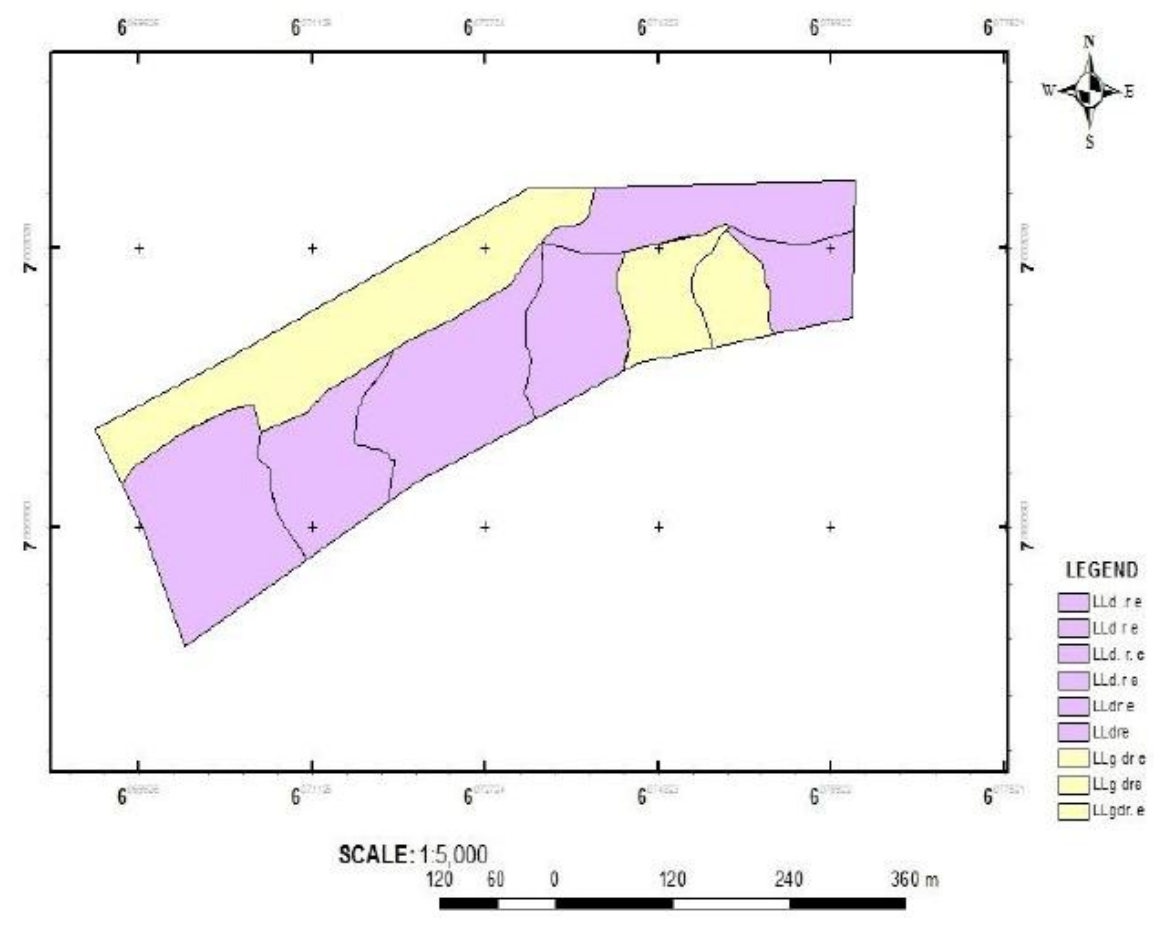

Figure5. Fertility capability classification of Kabba (Schist soils)

\section{REFERENCES}

[1] Bouyoucos, G.H. (1951). A recalibration of the hydrometer for making mechanical analysis of soils. Agronomy Journal. 43: 434 - 438.

[2] Bray, R. H. and Kurtz, L. T. (1945). Determination of total, organic and available forms of Phosphorus in soils. Soil Science, 59: 39-45.

[3] Bremner, J. M. (1996). Nitrogen: Total. In Methods of Soil Analysis. Part 3: Bigham, J. M. ed., SSSA book series No. 5. American Society of Agronomy, Madison, Wisconsin. 1085-1121.

[4] Das, A. (2015). Soil fertility capability classification as management options to remediate plant growth and production related constraints of some subtropical soils on varying parent materials and altitude. International Journal of Agricultural Science and Research (IJASR) 5(1): 115-124 ISSN (P): 2250-0057; ISSN (E): 2321-0087.

[5] Dickson, A. A., Allison-Oguru and Isirimah, N. O. (2002). Fertility capability classification based land evaluation in relation to socioeconomic conditions of small holder farmers in bayelsa state of Nigeria. Indian Journal of Agric. Science 36(1): 10-16.

[6] FAO (2016). The state of food and Agriculture Climate change, Agriculture and food security. Food and Agriculture Organization of the United Nations, Rome. 194pp.

[7] Geissen, V., Sanchez-Hernandeza, R., Kampichlerb, C., Ramos-Reyesa, R., and Sepulveda- Lozadaa, A. (2009). Effects of land-use change on some properties of tropical soil - An Example from Southeast Mexico. Geoderma 151, 87-97.

[8] Helming K., Tscherning K., König B., Sieber S.,Wiggering H., Kuhlman T., Wascher D., Perez- Soba M., Smeets P., Tabbush P., Dilly O., Hüttl R.F. and Bach H. (2008) Ex ante impact assessment of land use change in European regions: the SENSOR approach, in: Helming K., Pérez-Soba M., Tabbush P. (Eds.), Sustainability impact assessment of land use Changes, Berlin, Springer, pp. 77-105.

[9] Hillel, D. (2009). The mission of soil science in a changing world. J. Plant Nutr. Soil Sci. 172, 5-9.

[10] Jones, A., Stolbovoy, V., Rusco, E., Gentile, A. R., Gardi, C., Marechal, B. and Montanarella, L. (2009). Climate change in Europe. 2. Impact on soil, A review. Agron. Sustain. Dev. 29: 423-432.

[11] Lal, R. (2008). Soils and sustainable agriculture, A review. Agron. Sustain. Dev. 28: 57-64.

[12] Lal, R. (2009). Soils and food sufficiency, A review. Agron. Sustain. Dev. 29: 113-133.

[13] Lichtfouse, E., Navarrete, M., Debaeke, P., Souchère, V. and Alberola, C. (2009). Sustainable Agriculture. Springer, 1st ed., 645 p., ISBN: 978- 0- 481-2665-1.

[14] Sanchez, P.A., Buol, S.W., 1985. Agronomic taxonomy for wetland soils. Wetland Soils: Characterization, Classification and Utilization. International Rice Research Institute, Manila, pp. 207- 227. 
[15] Tabi, F. O., Ngobesing, E. S. C., Yinda, G. S., Boukong, A., Omoko, M., Bitondo, D. and Mvondo Ze, A. D. (2013). Soil fertility capability classification (FCC) for rice production in Cameroon lowlands. African Journal of Agricultural Research 8(119): 1650-1660.

[16] Walkley, A. and Black, I.A. (1934). An examination of the Degtjareff method for determining Soil organic matter and proposed modification of the chromic acid titration method. Soil Science Journal 37: 29 - 38.

Citation: Babalola, T.S., et.al. "Fertility Capability Classification of Soils in Two Agro Ecological Zones in the Basement Complex Zone of Nigeria” International Journal of Research Studies in Agricultural Sciences (IJRSAS), 2019; 5(4), pp. 37-43, http://dx.doi.org/10.20431/2454-6224.0504004

Copyright: (C) 2019 Authors. This is an open-access article distributed under the terms of the Creative Commons Attribution License, which permits unrestricted use, distribution, and reproduction in any medium, provided the original author and source are credited. 